This article was downloaded by: [Purdue University]

On: 18 January 2015, At: 20:43

Publisher: Routledge

Informa Ltd Registered in England and Wales Registered Number: 1072954

Registered office: Mortimer House, 37-41 Mortimer Street, London W1T

3J H, UK

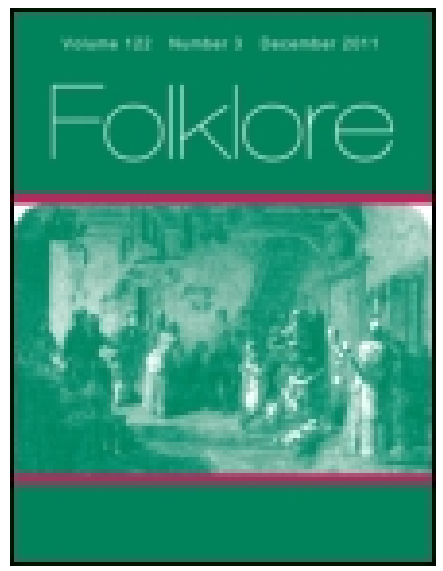

\title{
Folklore
}

Publication details, including instructions for authors and subscription information:

http:// www. tandfonline.com/loi/ rfol20

\section{The Holi: a Vernal Festival of the Hindus}

W. Crooke B.A.

Published online: 01 Feb 2012.

To cite this article: W. Crooke B.A. (1914) The Holi: a Vernal Festival of the Hindus, Folklore, 25: 1, 55-83, DOI: 10.1080/ 0015587X. 1914.9718804

To link to this article: http:// dx.doi.org/ 10.1080/ 0015587X.1914.9718804

\section{PLEASE SCROLL DOWN FOR ARTICLE}

Taylor \& Francis makes every effort to ensure the accuracy of all the information (the "Content") contained in the publications on our platform. However, Taylor \& Francis, our agents, and our licensors make no representations or warranties whatsoever as to the accuracy, completeness, or suitability for any purpose of the Content. Any opinions and views expressed in this publication are the opinions and views of the authors, and are not the views of or endorsed by Taylor \& Francis. The accuracy of the Content should not be relied upon and should be independently verified with primary sources of information. Taylor and Francis shall not be liable for any losses, actions, claims, proceedings, demands, costs, expenses, damages, and other liabilities whatsoever or howsoever caused arising directly or indirectly in connection with, in relation to or arising out of the use of the Content.

This article may be used for research, teaching, and private study purposes. Any substantial or systematic reproduction, redistribution, reselling, loan, sub-licensing, systematic supply, or distribution in any form to anyone is 
expressly forbidden. Terms $\&$ Conditions of access and use can be found at http://www.tandfonline.com/page/terms-and-conditions 


\section{THE HOLI : A VERNAL FESTIVAL OF THE HINDUS.}

BY W. CROOKE, B.A.

Tile Holi, the vernal fire-festival of the Hindus, has for a long time attracted the attention of students of anthropology and folklore, because it includes many features of special interest, and supplies material for the investigation of similar observances in other parts of the world. It seems, therefore, worth while to collect the facts scattered through a literature much of which is not readily accessible to European scholars; and, secondly, in the light of comparative studies by Dr. Frazer and others, to attempt an investigation of the principles upon which these observances are based. It will be convenient to begin with a statement of the facts so far as I have been able to collect them, and at the close of this paper to suggest an explanation of them.

The festival, known throughout Northern India as Holi, Phāg, or Phaguā, and in the Deccan and Western India as Shimgā or Hutāshana, takes place at the full moon of the month Phälguna, which in the year I913 occurred on 22nd March, the day after the vernal equinox, when the sun enters the sign of Aries. According to the present calendar, the Hindu New Year begins on Ist Vaisākha or Baisākh, corresponding according to the Bengali scheme with 14th

1 The Sanskrit form of the word is holakk, said to be derived from the sound made in singing: Phalguna takes its name either from the root phal (" to burst open or produce fruit"), or from sphurj ("to thunder"); Hutāshana is an epithet of the fire,- "oblation-eating." 


\section{The Holi: a Vernal Festival of the Hindus.}

April, 1913, or the 2Ist according to the Samvat reckoning. But in the older Hindu calendar system Sisira, or the cool season, ended with the full moon of Phälguna, and thus marked the beginning of spring. ${ }^{2}$

This at present, from the eccentricity of the Hindu lunisolar calendar, does not, in Northern India, represent a well-defined agricultural season. The wheat and other crops of the cold-weather harvest are sown about October, at the close of the rainy season; wheat in the Panjāb is reaped from about the end of April to the beginning of June, while in the United Provinces of Agra and Oudh the harvest is finished in March-April. The Holi thus takes place when the most important crops of the spring harvest are approaching maturity. It is a time of leisure from field work. The Hindu poets never tire of describing the spring as a period of rejoicing, and this time when the sun is moving northward in the heavens is the season for marriages.

We find little historical evidence regarding the Holi in Hindu classical literature, where it is obscured by the cult of Agni, the Vedic fire-god. The Sinhalese observe a festival at the beginning of spring, in commemoration, as they say, of the destruction of Māra, the fiend who tempted Buddha. This festival, known in Ceylon as Awaruda, is called by the Siamese Sonkran, the Sankrit sainkränti, the passage of the sun from one sign to another. The name and the legend connected with these feasts show that it is identical with the Holi of the Hindus. ${ }^{3}$

The feast commences with the lighting of the fire on the full moon of Phälguna, and usually extends over three days. But in some places the preparations and observances last

\footnotetext{
'See J. Prinsep, Useful Tables, Calcutta (1834), Part ii,, p. 18; Madiras Manual of Administration, 1893 , vol. iii., pp. 489 et seq. For the most recent and complete discussion of the question see A. A. Macdonell and A. B. Keith, Vedic Index of Names and Subjects (197), vol. i., pp. 259-60, 421 ; vol, ii., Pp. 157,466 et seg.

'I1. Kern, Manual of Indian Buddhism (1896), pp. I00-1.
} 
longer: some twenty days in Bombay, fifteen at Poona, and a week or more among the Bhils of Western India. ${ }^{4}$

In Northern India the pile is usually erected on a site east of the village, and consists of a layer of dried cow-dung cakes, the fuel commonly used by the peasantry, on which are placed logs, brushwood, and rubbish. The lighter fuel bursts into a sudden blaze through which men and animals pass or are driven. In places where the rite of fire-walking in its special form is observed, a pit is dug in which quantities of firewood are burned, and the performers walk through the blazing embers. The materials are provided by levies on the residents of the village or quarter in which the fire is lighted, or are collected from the jungle by the people who, as we have seen, are at leisure during this season. There is also a rule that the builders of the fire are entitled to plunder any fuel which they may require. In Chānda, in the Central Provinces, where, as we shall see, two fires are lighted, it is said that the materials must be stolen. ${ }^{5}$ In Poona cow-dung cakes are stolen for the fire wherever they may be found. ${ }^{\circ}$ In Lower Bengal " the head men of the villages, or the chiefs of the trades, first contribute their quotas; the rest collect whatever they can lay hands on-fences, doorposts, and even furniture, if not vigilantly protected. If these things be once added to the pile, the owner cannot reclaim them, and it is a point of honour to acquiesce; any measures, however, are allowable to prevent their being carried off." ?

- Gazetteer Bombay City and Island (1909), vol. i., pp. 175 et seq. ; Gazetteer Bombay Presidency, vol. xviii. (1885), Part i., pp. 254 et seq.; vol. vi. (1880), p. 29. For the rites in Mărwãr see J. Tod, Annals of Kajasthan (1884), vol. i., pp. 595 et seg.

- Chanda Gazetteer (1909), vol. i., p. 91. Compare the looting of fuel for bonfires in England, Folk-Lore, vol. xxiii. (1912), pp. 421 et seg.; vol. xxiv. (1913), p. 85 ; vol. xxi. (1910), p. 38. Miss C. S. Burne has kindly supplied these references.

- Bombay Gazetteer, vol, xviii. (1885), Part i., p. 292.

'II. II. Wilson, Essays and Lectures, chiefly on the Religion of the Hindus (1862), vol. ii., p. 227. 


\section{${ }^{8}$ The Holi: a Vernal Festival of the Hindus.}

We seem to reach a more primitive stratum of folk-usage when a tree, not a pile of firewood, is burned. ${ }^{8}$ In Kumaun, in the lower Himalaya, a middle-sized tree, or a branch of a large tree, is cut down and stripped of its leaves, each clan having a tree of its own. Young men of each clan beg scraps of cloth, known as Chir, from which the tree gains its name, and these are tied to it. A fire is lighted near the tree, and on the last day of the feast an astrologer fixes a lucky time for the burning of the tree. After it is burned the people leap over the ashes, believing that in this way they get rid of itch and other skin diseases. ${ }^{9}$ While the tree is burning there is a contest between members of the various clans, each striving to carry off a piece of the cloth from the tree of another clan. It is supposed to be lucky to succeed in doing this, and a clan which loses a rag in this way is not permitted to set up their tree until the insult is avenged.10

By another account from the same region, on the IIth day of the month Phãlguna, known as "Rag-binding Day" (Chirbandhan), people collect two small pieces of cloth from each house, one white, the other coloured, and offer them to the Sakti, or consort of Bhairava, an old earth god. Then they take a pole; split at the top, so as to admit of two sticks being placed transversely at right angles to each other, and from these the rags are hung. The pole is planted on a piece of level grourid, and the people move round it, singing the Holi songs in honour of Krishna and his cowherd girls, the Gopis. On the last day of the feast this pole is burned. Two days after thanksgivings are made for the birth of a child, a marriage in the family,

- Compare the burning of the tree in the agricultural ritual of the Celts, J. A. MacCulloch, The Religion of the Ancient Celts (191 t), pp. 200, 265.

- In Greece leaping thrice through a bonfire on St. John Baptist's Day (24th June) gets rid of fleas, J. C. Lawson, Modern Greek Folklore and Ancient Greek Religion (r910), p. 37.

${ }^{10}$ North Indian Notes and Queries, vol. iii. (1893), p. 92. 
The Holi: a Vernal Festival of the Hindus. 59

or some other good fortune. The officiating Brāhman is remunerated by a house cess, and he marks the donors on the forehead with turmeric."

The Biyārs of the United Provinces of Agra and Oudh "bury the old year" on the 13 th of the light half of the month Pũs (29th December, 19r3). They plant in the ground a stake of the cotton tree, and the Baiga, or village medicine-man, sets it alight. Stalks of barley are parched in the fire and eaten, and lumps of cow dung are thrown into the fire. Next day the ashes are thrown about, and people mark their foreheads with them. On the third day the men sing songs, and fling earth and cow dung at the women, and throw about coloured powder. The feast ends in general debauchery. ${ }^{12}$

The Red Karens of Burma set up a new post in or near the village every year in the month of April. The old posts are left standing, and are not renewed if they fall into decay. After the erection of the post there is a rude Maypole dance round it to the accompaniment of drums and gongs, and much drinking and eating of pig. ${ }^{13}$ That observant traveller, Dr. John Fryer, writing of the Karnātak, says: "In their Hooly, which is at their other Seedtime, I observed they cut a whole Tree down to the Roots, and lopped off the under-Branches till it became strait, they shoulder'd it with great Clamour, the Brachmin beginning a Note which they all followed: Thus they brought it into the Pale of their Pagoda, before which, easing it down at one end, the foremost made a Salam, and hoisted it with the same Noise again, and about they went three or four times repeating the same; which being finished, the Arch-Brachmin digs an hole, and baptizes

11 E. T. Atkinson, Gazetteer Himalayan Districts (1884), vol. ii., pp. 368 et seg.

$12 \mathrm{~W}$. Crooke, The Tribes and Castes of the North-Western Provinces and Oudh (1896), vol. ii., pp. 137 et seg.

18 Gazetteer Upper Burma (1900), vol. i., p. 529. 
6o The Holi: a Vernal Festival of the Hindus.

it with Holy Water, wherein they fix the Tree, crowning it with Flags aloft, and about the Body up to the Green Boughs they bind Wisps of Straw, to which they put Fire, and look earnestly on the Flame, according to the Ascent of which the Brachmin pronounces his Auguries: then they offer Rice and Flowers, painting their bodies with the Ashes, departing with a Mace of Flowers carried before them, beating of Drums and a great Noise." 14 In the Chānda District of the Central Provinces, a coconut is hung from a pole in the middle of the Holi fire; when it falls the people secure the burnt kernel, eat it, and smear themselves with the ashes from the fire. This coconut has been interpreted as a survival of human sacrifice, the nut bearing a curious resemblance to a human head; but this seems doubtful. ${ }^{15}$ The Pãvras, a forest tribe of Khāndesh, dig a pit, into which a wooden pole is thrust and lighted at night. ${ }^{16}$ In the Jabalpur District, in the centre of the fire a pole is fixed with a flag on the top. When it.burns the direction in which it falls is regarded as an omen,east and west being lucky; south, the home of the dead, unlucky; north, neutral. If the flag burns and floats up in the air, severe famine is indicated. ${ }^{17}$ In other parts of the same Province, one month before the Holi feast, a stick of the castor-oil plant, which possesses mystical powers of removing tabu or curing witchcraft, ${ }^{18}$ is fixed in the ground; and round it the materials for the fire are piled. ${ }^{19}$ In the Balaghat District, a piece of the sacred cotton-tree (semal) must form part of the pile. ${ }^{20}$

\footnotetext{
14 A New Account of the East Indies, ed. by W. Crooke, Hakluyt Society (1912), vol. ii., pp. 79.80:

15 Chanda Gazetteer (1909), vol. i., p. 91 .

10 Bombay Gazelteer (1880), vol. xii., p. 100.

22 Jubbulpore Gazetteer (1909), vol. i., p. 90.

10 W. Crooke, The Popular Religion and Folk-Lore of Northern India (1896), vol. ii., pp. 20, 275.

19 Yeotmal Cazetteer (1908), vol. i., p. 53.

20 Balaghat Gazetteer (1907), vol. i., p. 123.
} 
Sometimes certain things, regarded as "offerings,"-a theory which, as I shall try to show later on, seems to be mistaken,-are thrown into the fire. Thus, in the Rāigarh District, at the Holi feast, the village headman takes a hen, seven eggs, twenty-one cowry shells,--seven being a mystic number, - and some rice to the place where the fire is to be lighted, and there buries these things in a hole about a foot deep, and on the top of them plants a branch of the castoroil plant. It is not stated that the fire is built up round the branch, but, from parallel instances, this is probably the case. ${ }^{21}$ From many reports of such "offerings" they seem to be in the nature of firstfruits. Thus, in the Madras District of Nellore, a fire is lighted in every village, on which a cake is placed, and the right of bringing this is regarded as an honourable privilege. ${ }^{22}$ The Rāmoshis, a forest tribe in the Deccan, light a small heap of cow-dung cakes before each house, in the middle of which is set a small piece of sugar-cane, a copper coin, and five pieces of dried coco kernel. ${ }^{23}$ In Sambalpur, in the Central Provinces, the Mahalgundi or Gundikāi festival is held at the full moon of the month Phãlguna, the date of the Holi in North India. On that day, for the first time, people eat new gram, the fruit of the mango, and, among the lower classes, the mahua (Bassia latifolia) flowers, just as new rice is eaten at the Nuākhia festival, later in the year. These foods are eaten by the male members of the family, sitting together, facing eastwards. Some of the new food is offered to the family and village god. The Gonds of the same District offer fruits to their god, Būrha Deo; this is an offering of firstfruits, and takes place at the time of the Holi. ${ }^{24}$ Among the Pāvras, a forest tribe in Bombay, every one brings a piece of bread, some rice, and a cock; portions of these are

${ }^{21}$ Chhatisgarh Feudatory States Gaxetteer (1909), vol. i, p. 171.

${ }^{2}$ Nellore District Manual (1873), p. 195.

23 Bombay Gasetteer, vol, xviii. (1885), Part. i., p. 414.

24 Sambalpur Gazetteer (1909), vol. i., p. 87 et seq. 


\section{The Holi: a Vernal Festival of the Hindus.}

thrown into the fire, and the remainder given to friends. ${ }^{25}$ The Gaddis of the Panjāb Hills eat parched maize, apparently ceremonially, at the Holi.26 In parts of the United Provinces of Agra and Oudh, the presentation of firstfruits is absent, but some people throw into the fire cow-dung cakes and five sticks; they rub themselves and their children with the greasy condiment with which the bride and bridegroom are anointed before marriage, and, scraping the dirt thus produced off their bodies, they throw it into the fire. 27

Probably, in the more primitive form of the rite, the fire was lighted with "pure" fire, that produced by friction. But this custom, possibly under Brähman influence,-the production and maintenance of the sacred fire being novv specialized by the Agnihotra section of Brāhmans, ${ }^{23}$-does not seem to prevail at the present day. In the Deccan it is the rule that the Holi fire of the Mahār caste, now a body of degraded village menials, is started first, and from it that of the higher classes is lighted. But stealing the fire from them is a matter of some risk, because the Mahãrs are on the look out, and fling burning brands at the thief. ${ }^{29}$

As a rule, the lighting of the fire is the business of the householder or headman for the family and village fires respectively. Sometimes, as among the forest tribes, a man becomes possessed, and to him the duty is assigned. Among the more Hinduized castes and tribes, a Brāhman sometimes attends, supervizes the proceedings, repeats charms, and recites prayers. But, on the whole, the festival

${ }^{25}$ Bombay Gazetteer (1880), vol. xii., p. 100.

28 II. A. Rose, Glossary of Tribes and Castes of the Punjab and North-West Frontier Province (1911), vol. ii., p. 271.

${ }^{27}$ North Indian Notes and Queries, vol, v. (1896), p. 215.

${ }^{23}$ W. Crooke, The Tribes and Castes of the North. West Provinces and Oudh (1896), vol. i., Pp. 30-3.

20 Yeotmal Gazetteer (1908), vol. i., p. 53; Ethnographic Survey Central Provinces (IgI1), Part ix., p. 83: Bombay Gazetteer, vol. xviii. (1885), Part i.,
p. 292. 
is only vaguely connected with Hinduism in its orthodox form, except in Brähman-ridden parts of the country, like Lower Bengal, where the official Levite has compromised with, or adopted, this non-Brähman rite. Here he sprinkles the powder, conveys the image to the place where the fire is lighted, or performs rites which associate the observance with the cult of one of the higher gods, such as Krishna. ${ }^{30}$

The observances at the fire, except among the more Hinduized castes and tribes, seldom amount to actual worship. All that is done is that people ceremonially walk round it, as they do in the case of many other sacred things, keeping it on their right. Among the Ramoshis of Poona, the head of the house walks five times round the fire, sprinkling water from a pot. ${ }^{31}$ The Kunbis of the Deccan sit round the fire, and food is thrown into it, as has been already described. ${ }^{32}$ In Bengal the Brăhman in charge of the rite walks round the fire seven times. The observance is sometimes combined with the cult of Krishna, as in Orissa, where the Vaishnava worshippers of the god carry his image to the houses of their disciples, to whom they present some red powder and rosewater, and receive gifts in return. ${ }^{83}$ But it seems never to be connected with the cult of Agni, the Vedic fire-god, and there is good evidence that the fully developed fire-cult, in its modern form, is of later date than the Vedic age, and is largely due to missionaries from Irān, where, as among the modern Pārsis, it has been elaborated and systematized.

The ashes are valued as a preservative against all the vague forms of ill-luck, and as a protection against spirit agency. In the Central Provinces they are used to avert the Evil Eye, and for the cure of scorpion stings. ${ }^{84}$ In Central India the Mahrattas "cast the ashes upon one

${ }^{30}$ H. II. Wilson, op. cit., vol. ii., pp. 224 et seg.

s1 Bombay Gazetteer, vol. xviii. (1885), Part i., p. 414.

22 Ibid., p. 292.

33 H. H. Wilson, op. cit., vol. ii., p. 226.

4 Seoni Gazetteer (1907), vol. i., p. 50 et seq. 


\section{The Holi: a Vernal Festival of the Hindus.}

another, and throw them in the air, repeating their favourite extemporary stanzas, full of the grossest indelicacy, into which they freely introduce the names of their superiors, coupled with the most abominable allusions." ${ }^{35}$

The most interesting observance on the day when the fire is lighted is that of leaping through the flames, or walking on hot embers, usually collected in a pit dug for that purpose. At the village of Phalen in the Mathura District Mr. F. S. Growse observed that, though the heat was intense, "the lads of the village kept on running close round it, jumping and dancing and brandishing their lätlis [bludgeons], while the Pānda [village priest] went down and dipped in the pond and then, with his dripping pagri [turban] and dhoti [loin-cloth] on, ran back and made a feint of passing through the fire. In reality he only jumped over the outermost verge of the smouldering ashes and then darted into his cell again, much to the dissatisfaction of the spectators, who say that the former incumbent used to do it much more thoroughly. If on the next recurrence of the festival the Pānda shows himself equally timid, the village proprietors threaten to eject him, as an impostor, from the land which he holds rent-free simply on the score of his being fire-proof." 38

Since Mr. Growse witnessed the performance at Phalen, Captain G. R. Hearn has supplied further particulars. For some eight days before the Holi the Panda stayed in a mud hut near the village tank, spending his time in prayer and fasting, his only food being milk. A bonfire was made of wild caper branches with a substratum of cow-dung cakes. Before the pile was set alight women walked round it, and wound skeins of cotton round it. Some men postured in the village square dressed in long white garments, half stupefied with drink, and with their faces painted red. The

"T. D. Broughton, Letters written in a Mahratta Camp during the year 1809, ed. 1892, pp. 69, 71.

"F. S. Growse, Mathurd: a District Memoir, 3rd ed. (1883), p. 93. 
The Holi: a Vernal Festival of the Hindus. 65

fire-walking took place at night, according to some at an auspicious time fixed by an astrologer; but the Panda in his hut constantly passed his hand through the flame of a lamp, and, when this no longer burned his flesh, he declared that the hour had arrived. The fire was then lighted, and the villagers, armed with short clubs, circled round the fire, dancing and keeping the people away. The dry thorns blazed up fiercely, and, if the Panda passed through the flame at once, it would be a miracle if he escaped without severe burns. He leisurely disrobed, went to the tank, accompanied by an old woman, entered the water, and dipped two or three times, being dressed only in a turban and loin-cloth. The old woman preceded him on his return with a brass pot full of water, which she threw on the edge of the fire, and then the Panda jumped through it, sinking nearly to the knees in the burning cowdung, the flames of which, however, are not very severe. He is said to escape without singeing even the hair on his legs. He told Captain Hearn that he knew spells (mantra) which he communicates to his successor in office, but only on his deathbed. There was no suspicion that he was under the influence of drugs. ${ }^{37}$

The Bhils of Khāndesh, at the Holi, dig a hole four feet long and eighteen inches deep, which is filled with live coals. The priest mutters an invocation, fans the coals till they grow bright, offers a chicken, waves a sword six times over the fire, and then orders a Bhil to walk upon it. He takes six steps in the fire three times in succession. Mr. Horst, a European officer who happened to be present, suspected trickery, but he found that the feet of the performer were not burnt or blistered, and the same was the case with his orderly, a Muhammadan from Oudh, who volunteered to walk through the fire. ${ }^{38}$

Similar accounts from other parts of the country are

21 Man, vol. v. (1905), pp. 154-5.

3a Bombay Gazetteer, vol. xii. (1880), p. $93 n$. 
numerous. In the Nilgiri Hills, in Madras, fire-walking is done on the Monday following the new moon of February. The fire is lighted by an Udaya, or priest of Siva, who throws into it a coconut and some plantains, sprinkles a little holy water upon it, burns camphor and incense, and then leads the procession through the fire. ${ }^{39}$ At Coonoor, in the same District, during the fire-walking rite, a young bull is forced to go across the fire-pit before the devotees, and the owners of heifers which have given their first calf during the year take precedence of other people in the ceremony, and bring milk which is sprinkled on the burning embers. ${ }^{40}$ Among the Devangas of Cochin a member of the caste becomes possessed, and is regarded as a Velichapad or oracle-giver of the deity. He points out the place where the fire-pit is to be dug. It is filled with six or seven cart-loads of fuel, which is burned until it becomes a mass of glowing embers. The images of the gods are worshipped, and the castemen and others who are under a vow purify themselves with their priest, by bathing in the nearest tank or river. "The priest first walks on the glowing charcoal, and is at once followed by the castemen, who are in a state of fervent piety. Formerly they used to walk over it three times, but they now do it only once." 11

In another form of the rite a cart-load or two of wood is burned, and the red-hot ashes are strewn on the ground. The temple priest does worship, standing in a diagram representing flowers and drawn on the ground. Then $\mathbf{a}$

"Nilgiri Gazetteer (1908), vol. i., p. 325.

10 Ibid., vol. i., p. 339. Compare the custom in Ireland, when a man wearing a horse's head rushed through the flames, as surrogate or representative of all other cattle, J. A. MacCulloch, op. cit., p. 215. In Brandenburgh sickness of swine was cured by driving the animals through a fire, which was lighted by the friction of a rope, or by some similar device, F. B. Gummere, Germanic Origins (1892), p. 401: J. Grimm, Teutonic Mythology, Eng. trans, (1883), vol. ii., p. 605 .

'I. K. Anantha Krishna Iyer, The Cochin. Tribes and Castes, vol. ii. (1912), p. $3 \dot{6} 9$. 
Nambiyār Brāhman becomes possessed and treads down the red-hot ashes. ${ }^{42}$

Such rites are not confined to Hindus. In Gujarāt the Muhammadan Phãdali or "spirit-musician" becomes possessed. A pit is filled with hot embers, and a woman who has made a vow to perform the bahlim rite at marriage, in the seventh month of pregnancy, or at the initiation of a boy, comes up, and, keeping time with the Phàdali's song, takes the glowing coals in her hands, crushes them till they become black, and then dancing in the pit stamps out the fire with her feet. Cases do happen in which the firewalker suffers severe injury; but when this occurs it is attributed to the neglect of the rules of ceremonial purity, or to want of cleanliness in cooking the food for the feast, or in plastering the floor where the fire is lighted. ${ }^{43}$ At the feast of the Muharram a hole (aläwa) is filled with fire, and people with drawn swords jump over it, invoking the martyrs who are commemorated at this feast, with shouts of "Yā'Alì, Hasan, Husain, Dulhā,"-the martyrs and the bridegroom of the tragedy. ${ }^{44}$

It is impossible to discuss in detail the question of the immunity of the performer from burns in the course of the fire-walking rite. There seems to be little or no evidence that any special protective drugs or other substances are rubbed on the feet of the fire-walkers. In some cases it is clear that they do not walk actually upon the blazing embers, but on the sides of the pile or pit, or the embers are covered with a layer of ashes which do not readily conduct heat. To this may be added the fact that the feet of Indian peasants, accustomed to walk barefoot, become hardened like leather. Mr. N. W. Thomas writes:

4a Ibid, vol. ii., pp. 135-6.

"Bombay Gazetteeer, vol. ix. (1898), part ii., p. 151.

"16id, p. 135; S. II. Bilgrami, C. Willmott, Historical and Descriptive Sketch of H.H. The Nizan's Dominions (1883), vol. i., p. 360; G. A. IIerklots, Qanoon-e.Islam, and ed. (1883), p. 113 . 
- Primd facie we have no reason to suppose that a certain amount of auto-suggestive anaesthesia during the performance of the rite, followed by a suppression of inflammatory symptoms, for which European hypnotic clinics can supply parallels, will not suffice to explain the facts." 45

With the usual outburst of obscenity and sexual licence the proceedings of the first day of the Holi feast conclude.

On the second day follow the customs of flinging dust and other dirt, with coloured vater, on the spectators.

In the Bālaghāt District of the Central Provinces the people fling dust and cow dung on each other, and worship the local god, Gardeo, to whom women pray for the removal of barrenness. ${ }^{46}$ At Poona this takes place on the eleventh bright day of the month Phalguna, when the people visit their priest or a temple of Vishnu, where coloured water is thrown over them; from this time till the full moon they shout abuse on any one they meet, and rub red powder on their clothes and faces. ${ }^{47}$ Among the Rāmoshis of the same district, on the day after the fire is lighted, they throw filth at each other, pour mud out of a pot on any respectable man they chance to meet, and challenge him to a wrestling match; next day cow dung is flung on all well-dressed people. ${ }^{48}$ The red dust (abir) used in these orgies is usually made from the flour of the singhàra waternut (Traba bispinosa), which grows in tanks, and this is dyed with colour extracted from the red sandalwood (Pterocarpus santalinus), or it is tinged orange or yellow with the flowers of the $d h \bar{a} k$ tree (Butea frondosa).99 Broughton gives a curious account of the water-flinging in the Mahratta camp, when Sindhiya used for the purpose a hand fire-engine worked by a dozen men: "we were alter-

"san, vol. iv. (1904), p. 57.

4- Balaghat Gazetteer (r907), vol, i., p. 123.

at Bombay Gazetteer, vol. xviii. (1885), Part i., p. 254 it seq.

"B Ibid., p. 414.

10 G. Watt, Dictionary of the Economic Products of India, vol. vi. (1892), Part i., pp. 360 et seq. 
nately powdered and drenched, till the floor on which we sat was covered some inches in depth with a kind of pink and orange-coloured mud. Such a scene I never witnessed in my life." 50

At some places, on this day, the rite of swinging the images of the gods is performed. In the olden days the hook-swinging of a human victim fastened to a pole was done, but this, except perhaps in some very remote parts of the country, has fallen into disuse since it was prohibited by the British Government. In the Chhindwāra District of the Central Provinces the Bhumka or medicine-man of the forest tribes used to be swung on the Meghnād post at the Holi feast, a hook being fastened in the flesh of his back; now he is secured to the cross-beam by a rope..$^{51}$ In Hoshangābād the rite is known as "the swinging of the hero" (bir phirnā). "This was originally hook-swinging (charak pijja ), but the hook is nearly abolished now. In some villages, for the name of the thing, a hook is passed through the swinger's back, but his body is supported by a rope passed round his waist. Sometimes a pumpkin is swung round seven times, three one way and four the other. The man who swung used generally to be a man who had vowed to do it in case some wish was performed; if no such person appeared, some one had to be hired for the purpose. If a woman makes a vow, she climbs up the pole, but does not swing, and never did. The tall upright pole, painted red, with pegs in it to climb up by, is called Meghnāth, but there does not seem to be a reference to the brother of Rawun, or, at any rate, none is now understood. Almost every village of any size has a Meghnāth." ${ }^{2}$

$$
\text { io Op. cit., p. 67. } 1 \text { Chhindzwara Gazetleer (1907), vol. i., p. } 242 .
$$

${ }^{82}$ C. A. Elliott, Hoshungabad Settlement Report (1867), p. 126. Meghnäth would mean "Rain Lord"; but the proper term is Meghanāda ("Cloud, noise of rain or thunder"). Indrajit or Meghanāda was son of the demon Råzana, who appears in the Rảmáyana Epic. 
This leads us to the sexual conflict which occurs at the festival. I have elsewhere quoted the account of the custom at Mathura by Mr. F. S. Growse. ${ }^{53}$ Captain G. R. Hearne writes:- "At the other Jät villages in the northern part of the Mathura district, Jan and Bathen, a peculiar game is played about the time of the Holi. The men arm them: selves with branches of trees and form a ring, while the women with stout läthis or staves, and with säris [sheets] drawn over their faces, fiercely assault the ring and break it, soundly belabouring the men. Separate rings are formed by the Jāts and by the Chamārs [curriers] or low castes. Finally they return to the village in pairs, the man chanting a song, and the woman, when he has finished, driving him on a few paces." He notes that it is curious that the Jāts, supposed to be "Indo-Aryans," perform this rite. It is, however, now certain that the Jāts are descended from Scythians or Huns, who invaded Northern India. The rite was either introduced from abroad, or more probably is borrowed from the so-called "Dravidians." 54

Among the Gonds and other forest tribes of the Central Provinces, who have what is called by Hindustanispeaking observers "the breaking of the sugar ball". (gur tütnā) performed about the time of the Holi, "a stout pole, some twelve or fifteen feet high, is set up, and a lump of gur [coarse sugar from which the treacle has not been removed], with a rupee in it, placed on the top, and round it the Gond women ... take their stand, each with a little green tamarind rod in her hands. The men collect outside, and each has a kind of shield, made of two parallel sticks joined by a cross-piece held in the hand, to protect themselves from the blows. They make a rush together, and one of them swarms up the pole, the women all the time plying their tamarind rods vigorously; and it is no child's play, as the men's backs attest the next day. When

is Popular Religion and Folklore of Northern India (1896), vol. ii., p. 3i6. .

"Man, vol. v. (1905), p. 155. 
he gets to the top he takes the piece of gur and slips down, and gets off as rapidly as he can. This is done five or six times over, with the greatest good humour, and generally ends with an attack of the women en masse on all the men. It is a regular Saturnalia for the women, who lose all fear and respect even for a Settlement Officer; and on one occasion when he was looking on, he only escaped by the most abject submission, and presentation of rupees." ${ }^{55}$

Among the Bhils of Western India at the Holi "another of their frolics is to plant a small tree branch firmly in the ground. Round this men and women gather; the women round the tree, the men outside. One man rushing in tries to uproot the tree, when all the women set on him and thrash him so soundly that he has to retire. Another man steps in, and he too is belaboured, and makes his escape. Thus the play goes on, till one man luckier or thicker skinned than the rest, bears off the tree, but seldom without a load of blows that cripples him for days." ${ }^{66}$ With this we may compare the custom among the Kāfrs, at the Dizanedu festival in July, when women have the privilege of seizing men and ducking them in streams. ${ }^{57}$ In Madras, on the third day of the Holi, the Lambādis, gipsy-like carriers, sing, dance, and dress in gala attire. The men snatch away the food which has been prepared by the women, and run away amidst protests from the women, who sometimes chastize them..$^{58}$

It is significant, in this connection, that among the Bhils the Bhagoria, or day before the Holi, is the time when the young men and their friends abduct girls; some time after due payment of the bride-price is made, and the unions are legalized. ${ }^{50}$

ss C. A. Elliott, op. cit., pp. 126 et seq.

so Bombay Gazetteer (1880), vol. vi., p. 2I.

"Sir G. S. Robertson, The Kafirs of the Hindu-Kush (1896), p. 592.

BE. Thurston, Castes and Tribes of Southern India (1909), vol. iv., p. 230.

${ }^{\circ}$ Captain C. E. Luard, Ethnographic Survey, Central India (1909), p. 24. 


\section{The Holi: a Vernal Festival of the Hindus.}

The last of the distinctive Holi observances is the procession. These processions seem to be practically confined to Western and Central India. At Ajmer, the Oswāl merchants have a procession, in which a man known as the Rāo or "Chief" is dressed up as a bridegroom and, seated on a cot, is carried in procession through their quarter. Men and women pour red water through syringes on the Rão, who carries an open umbrella to ward off the deluge. At Beãwar in Rājputāna, a similar figure, called Bādshāh, "King," is led through the streets amidst singing and dancing, and is pelted with red powder. After the fête the Bādshãh in his robes is taken to pay his respects to the British Magistrate.00 Another observer thus describes the scene in Central India:- "The most remarkable incident of the day was a procession.... The principal figure in it was a fat merchant, who, after having been fully intoxicated, represented the companion of Holica. Bestriding a small donkey, his face smeared with ochre, a string of the most heterogeneous objects round his neck, and his head covered with flowers, he moved along, held upon the donkey by two staggering acolytes; and behind him came the travesty of a royal parasol, made out of the bottom of an old basket fastened on to a cane. His cortége consisted of a drunken and vociferous crowd of half-naked men and women, who howled and rolled themselves on the ground, like the chorus of the antique Silenus, and naked children, decked with flowers, ran in front, blowing earthenware horns or beating cracked tomtoms [drums]. In this order the procession traversed the mela, or fair, swollen by all the vagabonds on its route, and assailed by a shower of harmless projectiles, such as sacks of purple powder or rotten fruit. When it reached the plain a halt was made, and the crowd danced round the pseudo-Silenus, indulging in plentiful libations of the mowrah spirit." ${ }^{1}$ In Bombay, one of the most notable

- Gazetteer Ajnier-Merwara (1904), p. 40.

61 L. Rousselet, India and its Native Princes (1878), p. 345, with a drawing. 
observances at the Holi festival is the Varghoda, or "Bridegroom mounted on a horse" procession of the Pathāri Prabhus, who are Government servants, clerks, and pleaders. On this day a beggar boy was selected to act the part of bridegroom (var). He was mounted on a horse with his face to the tail and decked in tinsel. He paraded the city followed by a line of carts full of men disguised as dancing-girls, monkeys, and the like, and with persons dressed to represent popular and unpopular citizens or countrymen, and bearing appropriate mottoes and legends. ${ }^{62}$ By another account, the part of bridegroom was taken by a Brāhman, who was paid five rupees for the performance. He was dressed in a coat ( $j \bar{a} m a)$, and wore a cone-shaped, snuff-coloured turban, and rode on a horse, with a very long Chinese umbrella over his head. Some years ago the disorderly conduct at the procession led to its prohibition by the police authorities, but this was withdrawn in deference to an appeal by the Prabhu community. For seven years the procession was discontinued owing to the ravages of plague. I am not informed that it has since that time been revived. ${ }^{63}$

We are at once reminded by these processions of the Persian Ride of the Beardless One, which has recently been discussed by Dr. Frazer. ${ }^{64}$ An early account is that of Albiruni:05 "Bahar-cashn, the feast of the Riding of Alkausaj. This day was the beginning of spring at the time of the Kisras. Then a thin-bearded (Kausaj) man used to ride about, fanning himself with a fan to express his rejoicing at the end of the cold season and the coming of the warm season. This custom is in Persia still kept up

12 Gasetteer Bombay City and Island (1909), vol. i., pp. 175 et seq.

"s Balaji Sitaram Kothare, Findu Holidays (1904), p. 99.

4 The Golden Bough, 3rd edition, Part vi. (1913), The Scapegoat, pp. 402 et seg.: Sir R. Burton, $A$ Thousand Nights and a Night (1893), vol. iii., p. 93 n., quoting Richardson, Dissertation, p. lii.

os The Chronology of Ancient Nations (1879), p. 211. 
for fun." He was doused with cold water, ice and snow, and if people did not contribute when he halted at their doors, he used to befoul their garments with mud or a mixture of red ochre and water. Professor E. G. Browne has kindly translated for me another account from the best modern Persian Dictionary: "Kusa barnashin was the name of a festival amongst the Parsi (Zoroastrians) in Persia, in which on the first of the month Azar they mounted a man with a scanty beard [on a horse, mule, donkey, or the like], anointing his body with 'warm' drugs, and making him eat 'warm' food. He held a fan in his hand, with which he fanned himself, complaining of the heat, while the people on all sides pelted him with snow and ice, and gave him something [presumably money], and if anyone refused to give him anything, he used to pour over his [the refuser's] clothes ink or black earth, which he had with him. Thus he used to conduct himself for a certain definite period by permission of the authorities; but if he exceeded this permission, he was punished. The Parsis held the day in honour and respect, for they say that on this day Jamshid [first] brought pearls out of the sea; and that on this day happiness or misery is allotted to mankind by the predestination of God Most High. And the Arabs call this day Rukāb-i-Kūsaj [The Scantybearded Man's Riding]."

In this connection, it is interesting to note that in Central and Southern India a sort of mystery play is performed to commemorate the death of Kàmadeva, the god of love and fertility. The Kotas, on the first Monday after the January new moon, propitiate Kāma-tarāya by a feast said to be a continuous scene of licentiousness and debauchery. The observances include the lighting of a fire at a temple, music, dancing, and cadging for presents of grain and butter, which are cooked, offered to the god, and finally shared between the priests and the worshippers. Then follows a burlesque representation of a Toda funeral, in which the part of the 
sacrificial buffaloes is taken by men wearing buffalo horns and their bodies covered with black cloth. ${ }^{6}$ In the Chãnda District of the Central Provinces, at the Holi, two fires are lighted, and the festival is supposed to symbolize the death of Kāmadeva and the rejoicings at his rebirth. ${ }^{67}$ The Mannewārs, a tribe allied to the Gonds, perform a rite at the Holi which explains the lighting of the double fire. They make two human figures intended to represent Kāma, god of love, and Rati, his wife. The male figure is thrown into the fire with a live chicken or an egg. This, it is suggested, represents a human sacrifice, but this interpretation is, as we shall see, doubtful. ${ }^{68}$ In Bengal, after the flinging of the coloured water, "a bonfire is made on a spot previously prepared, and a sort of Guy Fawkes-like effigy, termed Holiká, made of bamboo laths and straw, is formally carried to it and committed to the flames. In villages and small towns the bonfire is public, and is made outside the houses. The figure is conveyed to the spot by Brahmans or Vaishnavas, in regular procession, attended by musicians and singers. Upon their arrival at the spot, the image is placed in the centre of the pile, and the officiating Brahman, having circumambulated it seven times, sets it on fire." ${ }^{89}$ A few years ago, at the Rāmgarh Hill in the Native State of Sirguja, south of Mirzapur, a record of a drama performed at the Holi festival, with a cave theatre in which it was acted, was discovered.70 We may suspect a survival of similar performances in the Holi observances now carried out in the Poona District, where boys dressed as dancing-girls take the place of women at the Holi festival, and perform a

\footnotetext{
"E. Thurston, Castes and Tribes of Southern India (1909), vol. iv., P. 14 et seq.

1 Chanda Gavetteer (1909), vol. i., p. 91.

"Elhnographic Survey, Central Provinces (1911), Part v., p. 66.
}

- II. H. Wilson, op. cit., vol. ii., p. 225.

10 A rchaeological Report, India (1903-4), p. 123 et seq. 


\section{The Holi: a Vernal Festival of the Hindass.}

baton dance (tipria), in which twenty or thirty young men move in a circle to the sound of a drum and pipe, each armed with a bludgeon, which they clash alternately against the sticks of the dancers before and behind them. Besides dancing, they play games, such as Tiger and Sheep, Fox and Dog, and Prisoner's Base. They also wrestle and perform feats of strength at the stone which embodies the demon Vetāla. ${ }^{71}$ When we remember the probable origin of the term Holi, and that a part of the rite is bawling and beating the mouth with the back of the hand, which elsewhere seems to be a sign of mourning, ${ }^{72}$ we may suspect that this is the wailing for the death of a vegetation deity, whose image has been consumed in the fire, perhaps combined with rejoicings for his resurrection, the orgiastic ritual of the present day disguising the primitive form of the observance.

Lastly, divination is practised by observing the smoke of the Holi fire. This is an ancient practice, since in the Atharvaveda we find mention of a functionary, known as "He of the Dung-smoke" (Sakadhūma), who used to predict weather for a traveller by observing the smoke of burning cow dung. ${ }^{3}$ Omens are also taken from the smoke of the fire-sacrifice (homa), and in Borneo from that of the funeral pyre. ${ }^{74}$. In Gujarāt, on the morning of the third of the light fortnight of the month Baisākh, a man sits in the open with a burning cow-dung cake in his hand. If the smoke moves towards the sun, there will be heavy rain ; if it forms a wreath and passes high over his head, there will

71 Bombay Gazetteer, vol. xviii. (1885), Part i., p. 293.

${ }^{72} \mathrm{~J}$ : G. Frazer, The Scapegoat, pp. 135, 207.

${ }_{73}$ M. Bloomfield, Hymn of the Atharvaveda, Sacred Books of the East, vol. xlii. (1897), p. 532. But this interpretation is not free from difficulty. A. A. Macdonell and A. B. Keith, Vedic Index of Names etc., vol. ii. p. 346.

"North Indian Notes and Queries, vol. v. (1896), p. 199 ; H. Ling Roth, The Natives of Sarawak and British North Borneo (1896), vol. i., p. 137. For divination at Midsummer rites, see J. G. Frazer, Adonis, Attis, Osiris, and ed. (1907), pp. 210 et seq. 
be partial or complete failure of rain. ${ }^{75}$ The mnemonic lines current in Northern India tell that if the smoke of the Holi fire blows to the west, the season will be good; to the east, the rain will be partial ; to the south, wealth will be destroyed, but hemp and grass will grow in their season; to the north, rain will surely fall. If the smoke blow to all four quarters of the sky, the people will be miserable, and the king will be slain; if the blaze go straight up to heaven, there will be war on the earth. ${ }^{76}$

Having thus, from a large collection of material, given a summary of the Holi observances, we may attempt very briefly to interpret their significance.

The rites are purely animistic, or pre-animistic; at any rate, they have no connexion with orthodox Hinduism. The otiose legends which profess to explain the rites are figments of a later age invented to bring it in line with Brāhmanism.

Thus, we are told, Holikā was a cannibal Rākhshasī or female demon, who levied a toll of a child daily. When one unhappy mother was forced to pay the tribute, she consulted a wise ascetic, who told her that the monster would fall down and die if she once were forced to listen to foul abuse. So, when she came to demand the child, the village boys and girls assailed her with ribaldry, and she died. But, to make assurance doubly sure, they immediately cremated her.7 It is, however, obvious that Holikā, the ogress, is only the impersonation or projection of the devouring fire: she was developed from the fire, not the fire from her.

Again, when the demon Tārakāsura oppressed the gods,

"S Bombay Gazetteer (1901), vol. ix., Part i., p. 353.

7'W. Crooke, Rural and Agricultural Glossary for the North-West Provinces and Oudh (1888), p. 125; cf. North Indian Notes and Queries, vol. v. (1896), p. 215.

7 S. M. Natesa Sastri, Hindu Feasts, Fasts, and Ceremonies (1903), pp. 42 et seg. 
they determined that Skanda or Kārttikeya, god of war, should be created to destroy him. They induced Kāma, god of love, to inflame Siva, who was then engaged in austerities, with desire to unite with his consort, Pārvati. Siva fell a victim to the temptation, but in his wrath he poured a flame of fire from his third eye on Kama, who was burnt to ashes. Hence the fire is lighted annually on the day of his death. ${ }^{78}$ The object of the story is clearly to associate the fire with the cultus of Siva.

Again, the pious Prahlāda was a follower of Vishnu ; but his father, a wicked demon named Hiranykasipu, to punish his son's apostacy, induced his sister, Holi or Holikāa, to torture Prahlāda. This scheme came to naught. She herself was burnt to death by Vishnu, who entered for the purpose into a pillar of red-hot iron. ${ }^{79}$ As before, the object of the tale is to associate the feast with the cultus of Vishnu.

We have seen that the festival marks not only the close of one of the seasons, but also the end of the year in its older form. It is thus a crisis, a No Man's time, a rite de passage, as M. van Gennep terms it. It is at such timies, for instance, during the intercalary months, that festivals in the nature of the Saturnalia, accompanied by ribaldry and obscene rites, very commonly occur. ${ }^{80}$ Such observances are associated with one or other of the chief agricultural seasons, especially with seed-time and harvest, or, as in the present case, with the death of the old and the rebirth of the new year. On the principles of mimetic magic, orgiastic rites are supposed to recruit and re-invigorate the exhausted energies of the year that has passed, and to promote fresh and healthy activity in the coming season. This is represented by the burning of Kāma, god of

\footnotetext{
78 Balaji Sitaram Kothare, op. cit., pp. 97-8: H. H. Wilson, op. cic., vol. ii., pp. 230 et seq.

7" Vishnu Purana, trans. II. 11. Wilson (1840), p. 126 et seq.: W. Crooke, The Popular Religion and Folk-Lore of Northern India (1896), vol. ii, p. $3 \times 3$.

${ }^{\circ 0} \mathrm{~J}$. G. Frazer, The Scapegoat, p. 328 et seq.
} 
fertility, or of the tree which is the more primitive form of the rite.

One of the agencies which help to secure the promotion of fertility is fire. It is both a purifier and an agency for the dispersal of mana. Among races which, like the Hindus, practise cremation of the dead, it slays the foul Pisāchas, the impersonation of bodily corruption, and releases the purified soul to join the Pitri, or sainted dead. It conveys the sweet savour, the mana of the sacrifice, with that of the firstfruits which are cast into it, and spreads their refreshing influence far and wide. Here the functions of the removal of the influences which check fertility and the invigoration of fertility itself meet and combine: the mana dispersed by the flames performs both objects. Hence it is hardly necessary, as Mr. Hartland does, ${ }^{81}$ in order to account for the practice of passing men or animals through the fire, to accept the theory of Mannhardt or Dr. Frazer that we have here a magical method of securing a due supply of sunshine, the sun being a well-known source of fertility, particularly as Dr. Frazer himself, in his last treatment of this subject, has abandoned this view.82 At the same time, some of us may still be inclined to accept the belief that, as in the case of the Celtic Samhain, ${ }^{83}$ men thought it necessary to assist the powers of growth which were in danger and eclipse in the winter, by the agency of fire.

¿ Primitive Paternity (1909), vol. i., pp. 99 et seg.

"Adonis, Altis, Osiris, and ed. (1907), p. 209 n. I. The Golden Bough, 3rd ed., Part vii., vol. i. (1913), pp. 341 et seg.

"I. A. MacCulloch, The Religion of the Ancient Celts (19I1), p. 26r. The curious Shan rite, in which bonfires are lighted in the cold season to warm the spirits of deceased monks embodied in the temple images of Buddha, in its present form at least, seems to be only a method of comforting the chilly couls of the dead. H. S. Hallett, $A$ Thousand Miles on an Elephant in the Shan States (1890), p. 265. In the Vedic age a rite known as the Mahavrata was performed at the winter solstice for the purpose of drawing away influences hostile to the return of the sun. A. A. Macdonell and HI. B. Keith, Vedic Index of Names and Subjects etc., vol. i., p. 368. 
The custom of leaping over the fire is, then, partly due to the belief that it is purgative; partly, that it promotes conception in women; partly, that the higher the leapers jump, the higher the crops are believed to grow. In the Greek rite of the Amphidromia the object is in part purificatory, and in part the object is to present the child duly to the sacred hearth. ${ }^{84}$ The two fires which in one of the Indian cases are lighted, one communal and the other domestic, may perhaps be compared with the Prytaneum and the family hearth respectively. ${ }^{85}$

In the case recorded from the Mathura District, the Panda or Kherapati is induced or forced to pass through the fire. The word Panda is a later title of this official; the more primitive name, Kherapati, means "Lord of the mound on which the village is built," the non-Brahmanical medicine-man, ghost-scarer, exorcist, who acts as priest, not to the orthodox deities, but of the village gods, the change of name indicating the gradual absorption of these gods into official Hinduism. He acts as the surrogate or representative of the community, and is provided with a glebe as remuneration for his services. This pretence of putting a man on the fire does not necessarily imply human sacrifice, though this may have been at one time part of the rite: the primary intention is that of purgation.

The drenching with water is usually interpreted as a magical rain-charm, as in the case of the dousing with water of the Oraon priest at the Sarhūl, or spring festival.86 But it seems also to be a fertility rite. Among the Krishnanvakkar caste in Travancore, the maternal uncle pours water into a palm leaf held by bride and bridegroom.87

" I. R. Farnell, The Higher Aspects of Greek Religion, Hibbert Lectures (1912), p. 28 ; Cults of the Greek States, vol. v. (1909), p. 356.

"J. G. Frazer, Journal of Philology, vol. xiv. (1885), p. I47; L. R. Farnell, Cults of the Greek States, vol. v. (I909), p. 350 ; J. G. Frazer, Pausanias, vol. iv. (1898), p. 44 I et seg.

a. E. T. Dalton, Descriptive Ethnology of Bengal (1872), p. $26 \mathrm{r}$.

"Travancore Census Report (1901), vol. i., p. 336. 
The Holi: a Vernal Festival of the Hindus. 81

Among the Badagas, bride and bridegroom pour water on each other's feet; the bride makes small pools of water, and when asked by her relatives who made them, replies "My father and my mother".88 Among the Patānē Prabhus, the kinsmen of the bride wash the feet of the bridegroom before he starts for the wedding. ${ }^{89}$ Among the Chakmas, an elder sprinkles rice water over the bride and bridegroom, pronounces them man and wife, and says a charm used for fruitfulness. $^{90}$ The use of water in gift-giving, and in particular for the giving of the bride, may be connected with the same idea. ${ }^{91}$

The colouring of the water with red or yellow dyes adds to the efficacy of the charm.

The sexual conflict, the fight between men and women in the Mathura observances, and the combat round the pole by the Gonds and allied tribes, seem to rest on varied modes of thought. It is, in part, probably merely orgiastic, associated with the license and relaxation of moral control which is common in such observances, the apotropaeic power of indecency being familiar in primitive ritual. ${ }^{.2}$ The Bhils, as we have seen, abduct girls at the Holi festival. Or, again, the blows administered by the women to the men in the Gond rite may be interpreted as a fertility charm.

The object of the pole-climbing is obscure. In one sense, it may be grouped with the custom of leaping over the fire as a mode of promoting the growth of crops: the higher the man climbs, the more vigorous is the life of the plant. A similar belief may account for the custom in the Central Provinces, when children and young men swing and walk

"F. Metz, Tribes Inhabiting the Neilgherry Hills (1864), p. 88.

"Bombay Gasetteer (1884), vol. xviii., Part i., pp. 207 et seg.

"T. 11. Lewin, The Hill Tracts of Chittagong (1869), p. 71 .

"11. T. Colebrooke, Essays on the Religion and Philosophy of the Hindus (1858), p. 132; The Jataka, vol. i. (1895), p. 17 12. 2, vol. iii. (1897), p. 280.

*2 J. Ilastings, Encyclopaedia of Religion and Ethics (1910), vol. iii., pp. 435 at seg. 
on stilts in the fields, or play with little grooved wheels of wood and brass, to which a long string is tied, the wheel being thrown into the air and dragged back again, the theory being that the crop will grow as high as the stiltwalker, or as long as the swing or wheel ascends into the air.93 The same is the case with the upward movement of the swing in which a man is pulled up and down, which, as we have seen, is part of the observances at the Holi. The circular movement acts as a mode of dispersing the mana of the victim, as in the case of the fire itself. These customs may be compared with that current in Southern France, where, at the midsummer fire-lighting, the man who was last married in the village, a type of fertility, has to climb up a ladder and bring down a garland of flowers fixed on the top of the tree, which is split and burned.94 In the same way, the procession, in its Indian form, seems to imply a sacred marriage or fertility charm. But in the Gond rite the name of the tree associates the custom with some obscure form of rain magic. We must also remember that these mock combats imply a contest between the powers of good and evil, in which the ultimate success of the influence of good is carefully arranged.

.Finally, we have reason to suspect that the divination from the smoke of the fire is a broken-down form of magic intended to cause rain or fruitful seasons. In more primitive thought the direction of the smoke did not foretell the. amount of rain: it caused the rain to fall.

It is hardly necessary to say that this attempt at the interpretation of the complex rites which are included in the Holi observances must be regarded as only tentative. Many of the facts which I have collected in this paper have been intentionally selected from the usages current in those Districts and among those tribes which have been least

.03 Betul Gazelteer (1907), vol. i., p. 91 ; Nagpur Gazelleer (1908), vol. 1.; p. 95 .

"J. G. Frazer, The Golden Bough, Part vii., vol. i. (1913), p. 192. 
affected by orthodox Hinduism. But in India the intermingling of the race types and the insidious but effective influences of Brahmanism have from a very early period been so continuous that it is difficult to sort out those observances which are really primitive and discard what is due to the orthodox priestly body.

On the whole, there seems to be some reason to believe that the intention to promote the fertility of men, animals, and crops supplies the basis of the rites. The object is, in essence, magical; but it is difficult to disentangle the varied forms of this magic, which operates either as directly pro. moting fertility, or as an agency for the removal of the forces which impede fertility, while in some cases we may suspect a more special intention, for instance, rain-making, the control of the seasons, or the fertilization of some particular crop.

The best chance of arriving at a solution of these questions lies in the hope that this review of an interesting and complex group of rites may suggest the need of further investigation, particularly in those Districts and among those tribes which have been least exposed to the influence of Brahmanical Hinduism.

W. CrOOKE. 